\title{
STRAY WRITING: NAVIGATING THE GREAT DERANGEMENT
}

\author{
Jack Kirne | Deakin University
}

\begin{abstract}
Many theorists have lamented the lack of serious literary fiction addressing the shifting realities of climate change, or ecological collapse. While the reasons for this lack are diverse, most hinge on the temporal dimensions of the Anthropocene. This paper-via a study of work emerging in the environmental humanities is an attempt to fragment the totalising rhetoric of geological shift by illustrating that the Anthropocene effects humans/non-humans on narrative timescales that are neither apocalyptic or gradual. In conclusion, drawing upon Barbara Creed's formulation of the stray (2017), I advocate for the stray novel and provide a series of provocations for further research.
\end{abstract}

BIOGRAPHICAL NOTE

Jack Kirne is a PhD candidate at Deakin University in the School of Communication and Creative Arts. His fiction has appeared in Voiceworks and Exposition Review. In 2016 he featured in the Wheelers Centre's The Next Big Thing.

KEYWORDS

Anthropocene-Creative Writing-The Great Derangement-Gradualism -Amitav Ghosh-Stray 
Despite an increasing focus on the Anthropocene in media, the writer Amitav Ghosh has lamented the lack of literary fiction on the topic. He writes: 'climate change casts a much smaller shadow within the landscape of literary fiction that it does even in the public arena ... We need only glance through the pages of a few highly regarded literary journals and book reviews' $(2016,: 7)$. This is not to suggest these Anthropocene texts do not exist, they do-Alexis Wright's The Swan Book (2013) is a notable example. Instead, it is to point out how few texts there are, and how few have won critical acknowledgement. A glance at Man Booker and Pulitzer Prize winner lists gestures toward the depth of this crisis. Ghosh terms this phenomenon, The Great Derangement (: 11), a time in which literature carried on as is, while the earth fell into crisis.

This paper sets out to challenge the limits of Ghosh's thesis and forwards what I label here as stray writing. To do so, I will necessarily tread some familiar ground for those acquainted with recent work in the environmental humanities. To make my argument, I will first provide an expanded summary of Ghosh's argument, alongside other critics who have argued that the Anthropocene or Climate Change resists the modern novel. Then, in the section, Breaking time down, I will unpack why the Anthropocene threatens gradualism, and the implications of this disturbance-specifically how a disturbed geology troubles western understandings of time, and its accompanying progress narratives. However, as this paper will explain, this disturbance does not affect all subjects equally, as the technologies of modernism have worked, and continue to work, to insulate privileged subjects from the biosphere. I will try to deconstruct the closure of possibilities posited by Ghosh by forwarding the figure of the stray. The stray, who is homeless in empire, contains the peculiar position of existing outside of gradualism, as their lives are not insulated from catastrophe. In conclusion, I hope to advocate for a stray environmental writing by providing a series of provocations for further research.

Ghosh has attributed The Great Derangement to the worldview from which the modern novel emerged. He argues that the modern novel and the gradualist view of geology developed concurrently (2016: 20). Throughout the eighteen century, gradualism or uniformitarian became the predominant means by which the natural world was understood. Under gradulalism, catastrophe was ejected from a modern worldview and deemed "primitive" (20), in favour of a belief in a measured, stable geology. Ghosh argues the modern novel shares this non-catastrophic worldview, rather than plotting the spectacular the novel creates the illusion of gradual plotting-its desire to mimic the everyday rather than the dramatic, which is relegated to the background (17). Consequently, the life of the novel shares the predictable reality of bourgeois life (23). Adam Trexler, who has provided one of the most comprehensive accounts of the 'clifi' genre argues a similar case regarding the cannon, noting the literary text's inward focus and how many texts revolve around the human (2015: 13). As a 
result, they argue that Climate Change or the Anthropocene more broadly, resists the literary form, due to its existential nature.

James Bradley's Strange Weather (2015) adds nuance to the impasse by considering the temporal elements of gradualism. Bradley laments the gradual, discreet, and lack of clear dramatism that characterises a gradualist worldview (2015: 56). Gradualism, or in Bradley's phrasing, climate, 'presents the literary imagination with a series of difficulties: how to dramatise aggregating detail, how to plot slow change' (56). How to write a story that exceeds the human, both in scope and in time? This is the fundamental difficulty of writing about the hyperobject (Morton 2012)-an object massively distributed across space/time, and a concept to which I will briefly return. Emmalie Dropkin has further considered the temporal difficulties of writing about climate change. Drawing upon psychological research, she notes that humans, when asked to consider questions of the future 'go dark' at the fifteen-year mark (2017). Consequently, 'cli-fi' texts, where apocalypse befalls protagonists, are likely to be encountered as abstract fantasies by readers who struggle to configure the temporal gap.

Under this framework, it appears the Anthropocene resists the literary novel for two reasons: its temporality exceeds "The Human"-socially, interpersonally, narratively-and therefore cannot be encapsulated by the time frames of the typical literary text or it is too catastrophic to exist within the rational, progressive narratives of western modernism. What I would like to begin to suggest in this paper, is that is possible to view the Anthropocene as something other than apocalyptic or gradual by focusing upon how shifting ecologies are shaping stray communities in the present.

\section{Breaking time down}

To understand the difficulty the Anthropocene presents to the modern novel as articulated by Ghosh it is essential to question how the Anthropocene affects time. Generally, the Anthropocene epoch is defined by the scale of human influence upon Earth system processes, to the level that humans are now conceptualised as the driving geological force on the planet. However, as many theorists have argued, this definition is problematic, as it implies all humans are equally responsible for creating and perpetuating the Anthropocene epoch. Consequently, many alternative designations for the Anthropocene have been forwarded to draw attention to the forces constructing the Anthropocene such as Haraway's Capitalocene and Chthulucene (2016: 5), Jean-Luc Nancy and Sloterdijk's Technosphere, Sloterdijk's Eurocene and Davis and Turpin's Plantationocene (cited in Davis and Turpin 2015: 8). While an exploration of these terms and their usefulness is beyond the scope of what I can do here, what 
binds them together are the social and economic processes that construct the Anthropocene. Davis and Turpin summarise some of these features well:

[The Anthropocene is] 'the rise of agriculture and attendant deforestation: the extraction of coal, oil, and gas, and their atmospheric consequences; the combustion of carbon-based fuels and emissions; coral reef loss; ocean acidification; soil degradation; a rate of life-form extinction occurring at thousands of times higher than throughout most of the last halfbillion years; and, perhaps most suprisingly, a rate of human propagation-a completely unabated explosion in population growth-which, according to the renowned biologist E.O Wilson, is "more bacterial than primate"' (Davis and Turpin 2015: 4).

Critically, these ecological catastrophes stand to alter the planet's geological patterns for at least the next 10,000 years (Hamilton 2017: 4). These social and economic pressures can mainly be attributed of the technologies of industrial growth capitalism supercharged by the post-world war II period, sometimes referred to as The Great Acceleration (Haraway 2016: 4) The Anthropocene's significance, in this context, is threatening because it threatens the viability and desirability of the dominant economic and social practices on the planet.

Indeed, philosopher Timothy Morton said that 'the end of the world has already occurred' (2012: 7). By this, he does not mean to claim the earth has ceased to be, but that the human (read: western colonial) understanding of the earth is no longer tenable. The steam engine, Hiroshima and Nagasaki, he argues, altered human history. Each has or contains the capacity to radically alter the biosphere, detonating the belief that the earth would always sustain human life (5). Global Warming has furthered this realisation. These world-changing events, Morton argues, are all part of coming to terms with the 'hyperobject', 'things that are massively distributed in time and space relative to humans' (2012: 1). Critically, the hyperobject earth detonates long-standing narratives that position humans as possessing nature (5) as per Genesis, as shifts in ecology and biosphere health threaten to kill or displace humans. In another formulation, the hyperobject detonates the myth of human transcendence and the accompanying progress myths: for instance, modernism.

Morton is not alone in his claim that the Anthropocene disturbs the temporalities of modernism. Historians Christophe Bonnuil and Jean-Baptiste Fressoz have argued that the Anthropocene marks 'the reunion of human (historical) [read western/colonial historical] time and Earth (geological time)' (2017: 32). The belief that humanity is making its own history is no longer 
viable. As geological time pressures human decision-making processes, the western delusion of being above or in control of nature becomes less viable. Michelle Bastian (2012), Katy Rigby (2009), Whitney A. Bautman (2015), Nicole M. Merola (2014), Jacob Metcalf and Thom van Dooren (2012), have considered at length how a construction of time bound to both human and nonhuman agents might be understood. Moreover, while a proper explication of their work exceeds the possibilities of this paper, what braids their thinking together is the idea is that the Anthropocene presents what Mackenzie Wark has termed a 'third temporality' (2017), a time-space that is neither predictable, progressive or apocalyptic, but something in-between.

\section{'Patchy' gradualism}

At this point, reflecting on this idea of in-betweenness, I would like to return to Ghosh's claim regarding gradualism's embeddedness in the modern novel. Indeed, if I am to follow Ghosh's claim that gradualism is intrinsic to the literary novel, the temporal upheaval posited by the Anthropocene problematises the form by revealing novel time and geologic time to be "out-of-sync". Which begs the question: If the Anthropocene has brought about the end of the western world, is the novel, that ticks to the steady beat of gradualism, viable?

In The Great Derangement, Ghosh argues gradualism was essential to the colonial project. Writing about colonial settlements such as Mumbai, New York, Hong Kong he notes that many of the residents were resistant to move to such cities so prone to catastrophe (2014: 55). To reconfigure, those people who lived with an ancestral understanding of the land, were sceptical of low-lying cities, because they feared catastrophe. These first global cities, however, which required a regularity of fast exchange over oceans, necessarily ignored these knowledges. Catastrophe, in other words, did not fit with a model of the world that could be conquered and was therefore ejected. This is not to suggest catastrophes stopped happening: natural disasters are commonplace. This term, disaster, is telling-it implies that significant weather events are somehow unexpected, or freakish.

Of course, as Ghosh argues, ecological catastrophe has and continues to be unpredictable, violent and beyond human control, and to weigh heavily on the human psyche (2016: 11-16). Alexis Wright has powerfully challenged the compulsion to view ecological events as disastrous in her essay, Deep Weather (2011). Reflecting on narratives around bushfires and cyclones, Wright considers how many weather events considered to be freakish and unprecedented in Australia, have long recorded histories among Indigenous people. Catastrophe then, is only unexpected in the frame of the coloniser. 
I suspect this willingness to dismiss deep histories has much to do with the ideology of progress, which propagated alongside the colonial projects. Many scholars note that progress is frequently registered by the human capacity to transcend supposed barriers of ecology. Drawing upon Val Plumwood's Shadow Places, Whitney A. Bauman argues that 'the logic of mastery helps to build the illusion that we are somehow beyond the cycle of death and decay' (2015: 748). Bauman points to the technology's capacity to remove people from waste, 'food ... from its relationship with the Earth and other life, and to secure our bodies from the rest of the natural world, not to mention securing white bodies from brown ones' (2015: 748-749). In short, this technology works to divorce societies from perceived decay and therefore disrupts the temporarily between life and death. Similarly, the progress fantasy has long upheld the belief that colonial powers can transcend local populations: historians Christophe Bonneuil and Jean-Baptiste Fressoz have noted that the desires in Jules Verne's in Five Weeks in a Balloon or Around the World in Eighty Days promoted the great Western fantasy of the time ... to penetrate into dangerous and barbarous extra-European places in a safe and technological European Bubble: balloons flying over Africa or trains crossing India' (2017: 265). Consequently, the ideology of progress works in tandem with gradualism, to forward an understanding of the world that is steady, and where human agents are bound toward a transcendence over the other.

Gradualism, as I have attempted to argue, is a fictional tool that upholds progress narratives that sustains certain economies, social customs and populations and the expense of others. It is this otherness, those lives lived against, between or beyond the insulating technologies and fictions of gradualism and modernism that provides a productive site for inquiry. In Anna Lowenhaupt Tsing's The Mushroom at the End of the World, she asks: 'How might capitalism look without assuming progress? It might look patchy' (2015: 5). Using Matsutake, a mushroom that thrives in "patches" of ecological devastation but can't be farmed as a guide, Tsing catalogues a market of buyers, traders, and foragers who are often immigrants and refugees to America. Collectively, they operate a private economy in industry's ruins, that exists within, while also complicating the neat, growth narratives that assume capitalism consumes everything. She terms this process salvage capitalism (6366). My interest in these 'patchy' sites is post-gradual. Matsutake appears in sites of sudden, and disastrous ecological devastation-whether this is in cleared forests (6), or in the wake of Hiroshima's destruction (3). These are sites in which the hyperobject manifests and renders the earth once again dangerous and beyond control.

I would like to consider what a 'patchy' gradualism might look like. Gradualism may be intrinsic to empire, and therefore, reproduced in the narratives empire celebrates. But this does necessarily foreclose the conclusion that gradualism is 
essential to the modern novel. After all, while the project of modernity has worked to insulate western bodies from catastrophe, and more specifically, ecological catastrophe, this has not removed catastrophe from human life.

\section{Stray lives}

Coming to question the limits of Ghosh's gradualist hypothesis necessarily requires a questioning of why ecological catastrophe is seldom critical to literary texts. Many feminist, indigenous and queer scholars have rightfully argued that there is a tendency to view the Anthropocene has a crisis that will unite all peoples, a belief that they rightfully argue is complete nonsense. Elspeth Probyn enunciates it perfectly:

'There is a pervasive sense that the big issues of the Anthropocene override the concerns of feminists, queers, and postcolonial people, and the questions of race and class. The idea that we are all brought together, that our differences are elided by living under the shadow of the Anthropocene, is, of course, nonsense. We are not nor will we be all equally affected by the multiple disasters occurring within the rubric of the man-made Anthropocene. (Probyn 2016: 12)

Reflecting on this insight, it is worth considering that the reason many texts have held up the narrative of gradualism past its viable end-point, is because the mechanics of modernism have managed to insulate wealthy, western, tertiary educated consumers - the kind of people who largely predominate in academic and literary institutions - from the ecological realities of the world. In other terms, what I am arguing here is that it might be entirely possible that the unfolding catastrophe of our present fails to collapse into the novelistic because many writers are insulated from catastrophe. Gradualism may be relevant to some literary texts, but perhaps not as crucial as Ghosh suggests. In a sense, many writers are perhaps not unlike those characters in the balloons of Jules Verne's novels, insulated from any form of perceived chaos or disorder below.

As I have outlined, critics such as James Bradley have argued that climate change is challenging to narrativise due to its temporality: it is just too large, too gradual and too impersonal to fit neatly into the narrative possibilities of the literary novel. But how gradual, or impersonal are those narratives to communities in the Amazon, who have seen their way of life uprooted in a generation due to deforestation? (Davis and Turpin 2015: 4) Or what about Torres Straight residents, whose are watching sea-walls fail? (SBS 2018). The notion that ecological catastophe somehow exceeds the human, and is 
fundamentally beyond comprehension, does not stand up to analysis. By paying attention to lives that do not exist within the insulating frame, it is clear that for many subjects, lives are lived amidst catastrophe.

In Barbara Creed's Stray: Human-Animal Ethics in the Anthropocene, Creed conducts a polemic study that focuses on the literary and philosophical figure of the stray. Drawing upon a collection of human and animal histories, she argues for a Stray Ethics, a system that highlights the shared fate of animals and humans alike, and advocates for a position that 'focus[es] ... on the most marginalised, whether an individual, group or entire species-human and nonhuman' (2017: 99). To make her case, Creed draws upon film, literature and art, to explicate the collective terror humans and animals have experienced, or will come to experience: that being that they will become homeless or refugees in the next century. From among this chaos, she states 'the human species is in danger of becoming a stray unto itself, a lost species whose ground of being, both literally and ethically, is shifting so rapidly that the darkness engulfs the way ahead' (168). The only escape is to invest in 'the interrelatedness, resilience and inventiveness of all species' (168). For Creed, a critical part of making art in the Anthropocene is to stray-it is to move between ruin, forging a life.

The figure of the stray, while seldom articulated in Creed's terms, appears throughout a great deal of literary and sociological research of the Anthropocene. In her collection of auto-fictional essays, ethicist Kathleen Dean Moore has attempted to stray through a process of nature-walking, cataloguing absences-of finches, of starfish, of penguins, of bears and more-between our present and near future of 2025 through an art of 'joyous attention' (2016: 75). The previously mentioned Anna Lowenhaupt Tsing's The Mushroom at the End of the World (2015) focuses its attention on a stray market of buyers, traders, and foragers (often immigrants and refugees to America), operating beyond the regulated market, whose very lives posit a life outside capitalism.

Critically, the stray is not a benign figure. By their very existence, strays question the so-called Naturalness of systems, whether this is economic, sexual or cultural. In Strangers in their Own Land (2016), Arlie Russell Hochschild journeys out to the state of Louisiana to explore what she terms 'The Great Paradox', that those people who would profit the most from government regulation are the most resistant to it (9), or through her keyhole focus, 'that red [read anti-regulation, free market, tea-party] states suffer higher rates of industrial pollution than do residents of blue states' (79). From her research, she concludes that the question of writing toward environmental and economic issues must go beyond treating people who oppose government intervention as being ignorant of "the truth". There is a complex affective fall-out to economic policies, creating a narrative of distrust, that can cause people to blame incursions on the once "functional system". An America that helps the poor that 
is pro-queer, equal opportunity and subject to environmental regulation is viewed as perverse by traditionalists, as it invites the stray into the fold. These 'cultural externalities' or strays-in this context marginalised human and nonhuman animals - are reduced to a general equivalence, as belonging to a similar existential terror as climate change, a pressure that realigns the subject's environment. For conservative notions to endure, strays must be kept in the wilderness.

\section{Stray writing}

What I hope to suggest by drawing these strands together is that from the stray, there might be the possibility to write an Anthropocene text that resists the clichés of the apocalypse, and question what it is to live in a diminishing world. I can see no reason as to why these lives, which exist in the volatile timespace of the present moment, can not be rendered in the literary form. The catastrophes to which they have been exposed-that being the displacement of their economic and social livelihoods by rapidly shifting economies do not seem terribly at odds with the modern novel.

Indeed, by reading back into the archive, a wealth of Anthropocene texts might present themselves. Examples leap to mind: surely Jack Gladney from DeLillo's White Noise (1984), who is physically displaced from his family, and sense of safety at home by an Airborne Toxic Event, is a stray. Perhaps less obviously, the protagonist of Delia Falconer's In the Service of Clouds (1997), Eureka Jones, whose hometown Katoomba decays with the fading of clouds, is another. I am particularly captured by Kevin Barry's Beatlebone (2015), that reflects upon the Irish frontier, where cults, radical political projects, and washed up musicians landed in the latter half of the twentieth century. And then, of course, there is non-western literature. Alison Ravenscroft noted in her review of Alexis Wright's The Swan Book, there is the possibility that all Indigenous texts after 1788 are post-apocalyptic (2013). Gradualism need not apply.

Each of these novels, among others, provide fertile ground from which stray writing could be developed. However, I have not afforded myself the scope to do so here. Instead, I would like to forward a set of provocations of what stray writing could potentially entail.

First, and foremost: A slow-moving geology should be troubled in the stray text. Previously, I have summarised Ghosh's argument that the modern novel emerged alongside gradualism, and the colonial ideologies that accompanied it, and therefore, the novel became non-catastrophic and aligned with the regularity of bourgeois life (Ghosh 2014: 17-21). To resist the bourgeois 
regularity of the literary text, the stray novel should reject stability, both structurally and in genre.

The stray novel should genre-hop, or stray across genres to create texts that are at once, "Literary", but also mythic, aware of their construction. Falconer's aforementioned The Service of Clouds is a terrific example: it is a mythic history of the air, set in the Australian Blue Mountain's town, Katoomba. As the town industrialises, the clouds dissipate or appear threatening, as German Eagles (1997: 201) or Zeppelins (253). Writing that draws readers into the wilderness is critical, as it activates what has 'been strayed' from the present social order.

The other fundamental tenant to stray writing is an attunement to place. Stray writing, which deviates from the human-only perspective that progressive ideologies enable, must be aware of how the biosphere informs and shapes narrative. The act of listening to place is radical, particularly in the Anthropocene epoch, because by becoming attuned to how the biosphere moves, changes and interacts with human and non-humans agents in the text, the dominance of gradualism is troubled. If ecology can infect the day-by-day lives of protagonists, the subject's world is rendered liminal, the shadow places of ecology (Plumwood, 2008), collapse into those places deemed safe.

What I hope is that I have begun to posit the possibility that the novel can work past the barriers presented by Ghosh and others. I acknowledge that the work I have begun to undertake here is just that, a beginning. It occurs to me, with a turn of optimism that is not entirely academic, that it might be literature that is best equipped to tell these stray stories. They are too small and too nuanced to capture in a statistic or political rhetoric, but human enough for empathy. 
Works Cited List

Barry, K 2015, Beatlebone, Canongate Books, Edinburgh

Bonneuil, C, Baptiste, F 2017, The Shock of the Anthropocene, trans. Fernbach D, Verso, New York

Bradley, J 2015, 'Strange Weather: Writing in the Anthropocene' in The Best Australian Essays, Black Ink, Collingwood, Melbourne

Creed, B 2017, Stray: Human-Animal Ethics in the Anthropocene: Power Polemics, Power Publications, Sydney

Davis, H, Turpin, E 2015, 'Art and Death: Lives between the Fifth Assessment \& the Sixth Extinction', in Art in the Anthropocene: Encounters Among Aesthetics, Politics, Environments and Epistemologies', Open Humanities Press: 3-31

DeLillo, D 1984 (2011), White Noise, Picador, London

Dropkin, E 2016, 'We Need Stories of Dystopia Without Apocalypse', Electric Literature: https://electricliterature.com/we-need-stories-of-dystopiawithout-apocalypse-73b3c15b5ee (accessed 11 Novemeber, 2017)

Falconer, D 1997, In the Service of Clouds, Pan Macmillan, Sydney

Ghosh, A 2016, The Great Derangement, University of Chicago Press, United States of America

Hamilton, C 2017, Defiant Earth: the fate of humans in the Anthropocene, Cambridge, UK; Malden, MA: Polity, 2017

Haraway, D 2016, Staying with the Trouble: Making Kin in the Cthulucene, Duke University Press, London

Hochschild, AR 2016, Strangers in Their Own Land: Anger and Mourning on the American Right, The New Press, New York

Moore, KD 2016, Great Tide Rising, Counterpoint Press, Berkley

Morton, T 2013, Hyperobjects: philosophy and ecology after the end of the world, University of Minnesota Press, Minneapolis

Probyn, E 2016, Eating the Ocean, Duke University Press, Durham

Ravenscroft, A 2013, 'After the apocalypse: despair, hope, and all things between', The Sydney Morning Herald:

http://www.smh.com.au/entertainment/books/after-the-apocalypsedespair-hope-and-all-things-between-20131002-2utda.html (accessed 28 August 2017) 
SBS 2018, "This place is a danger zone: Torres Straight residents evacuate as tides breach new $\$ 24 \mathrm{~m}$ seawall", SBS online:

https://www.sbs.com.au/nitv/nitv-news/article/2018/01/31/placedanger-zone-torres-strait-residents-evacuate-tides-breach-new-24mseawall (accesed 22 February 2018),

Trexler, A 2015, Anthropocene fictions: the novel in a time of climate change, University of Virginia Press, London

Tsing, AL 2015, The Mushroom at the End of the World: on the possibility of life in capitalist ruins, Princeton University Press, Princeton

Wark, M 2017, 'On the Obsolesce of the Bourgeois Novel in the Anthropocene', Verso: https://www.versobooks.com/blogs/3356-onthe-obsolescence-of-the-bourgeois-novel-in-the-anthropocene (accessed 25 August 2017)

Bauman, WA 2015, 'Climate Weirding and Queering Nature: Getting Beyond the Anthropocene', Religions, vol. 6, no. 2: 742-754. doi:

10.3390/rel6020742 (accessed 22 February 2018)

Wright, A 2013, 'Deep Weather' in Meanjin, 2: 70-83

Wright, A 2013, The Swan Book, Artarmon, Giramondo, NSW 